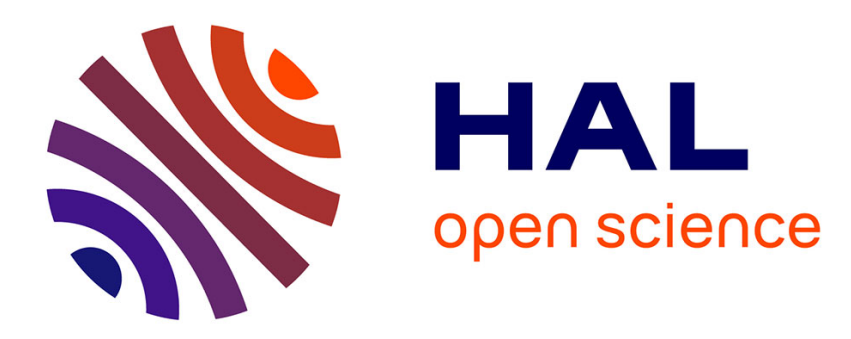

\title{
Globalization, Transnationalism, and the Local in Ancient Greece
}

Christel Müller

\section{To cite this version:}

Christel Müller. Globalization, Transnationalism, and the Local in Ancient Greece . Oxford Handbooks Online, Classical Studies, Social and Economic HistorY, 2016, 10.1093/oxfordhb/9780199935390.013.42 . hal-01668503

\section{HAL Id: hal-01668503 \\ https://hal.parisnanterre.fr/hal-01668503}

Submitted on 20 Dec 2017

HAL is a multi-disciplinary open access archive for the deposit and dissemination of scientific research documents, whether they are published or not. The documents may come from teaching and research institutions in France or abroad, or from public or private research centers.
L'archive ouverte pluridisciplinaire HAL, est destinée au dépôt et à la diffusion de documents scientifiques de niveau recherche, publiés ou non, émanant des établissements d'enseignement et de recherche français ou étrangers, des laboratoires publics ou privés. 


\section{Globalization, Transnationalism, and the Local in Ancient Greece \\ Oxford Handbooks Online}

Christel Müller

\section{Abstract and Keywords}

This article examines the idea that Greek poleis were interconnected in different types of networks and that localism and the notion of the local are byproducts of globalism. It considers how Greek cities interacted through multidirectional relationships by focusing on the relationship of the polis to transnationalism and globalization. It first discusses the concept of spatial turn before turning to the interactions between poleis through supracivic structures. It then addresses the tension felt by Greek communities between the inside and the outside, the local and the global, and the civic and the supra-civic, along with the dream of insularity as a polis ideology. It also analyzes the Greek poleis' control over civic bodies and borders, especially the movements of people in and out of cities. The article suggests that localism may be better understood through the neologism of (g)localism instead of "parochialism."

Keywords: networks, localism, Greek cities, polis, transnationalism, globalization, spatial turn, supra-civic structures, (g)localism, parochialism

\section{Introduction}

The polis, understood as a city state, has long been the sole frame of reference for both ancient philosophers and modern historians in their interpretation of Greek politics. In the middle of the fourth century BCE, the Platonic dream of the ideal city, an extreme case, was that of the Magnètai, a polis without neighbors. Responding to the Athenian's question of whether there "will ... be any State bordering close on it," Clinias answered, "None at all, and that is the reason for settling it" (Plat., Laws 4.704c; Bertrand 2005). Around the same time, although with a different agenda, the orator Isocrates also provided an excellent view of what a political territory was for a Greek: a city. He saw 
Athens as a megapolis, reflecting both on Athenian domination over the classical world and the difficulty of imagining a territory that would not be that of a city. According to him, Athens was termed by some people the "urban center of Hellas" (astu tès Hellados; Antidosis 299), "both because of her size and because of the resources which she furnishes to the rest of the world"; "she has established the Piraeus as a market in the centre of Hellas" (emporion en mesô tès Hellados; Panegyricus 42).

Modern historians have therefore often taken the polis as the basic and ultimate model, which also fitted the contemporary conception of the nation-state. The description of the Greek city given by M. H. Hansen since the 1970s (with the Copenhagen Polis Center since the beginning of the 1990s) definitely rests on the nation-state model, defined as a combination of a territory, a people, and a government, although Hansen is aware of the necessity to historicize the concept of state when it is applied to Greek antiquity (Hansen 1998, 112-13). The Inventory of Archaic and Classical Poleis, published in 2004 as the result of a vast enquiry into all existing cities in the Greek world between the eighth century BCE and the age of Alexander, is based on this conception, which focuses on individual items, and encompasses the description of 1,035 cities, improving our knowledge in a spectacular way and compelling historians to move beyond any Athenocentric view. The same diversity applies to the Hellenistic period, mostly accessible through the study of inscriptions; here the epigraphists have played an essential role, providing insights into a considerable number of institutions and political practices over hundreds of Greek poleis (e.g., Rhodes with Lewis 1997). The institutionalist perspective has not been the only one though, as shown by Edward Cohen's brilliant essay, The Athenian Nation: the author rejects vigorously the permanent focus on the "administrative organization of the politai" (2000, x) and proposes to look at classical Athens (his case study) not as a polis (taken as the group of adult male citizens), but as a nation, that is, an ethnos, including all the layers of population. Cohen was not the first one to think that way, and anthropologists have been very active since the 19601970s, especially in France with the so-called École de Paris, in trying to understand behaviors and rituals inside "the" Greek city (for an excellent and recent overview of both the "cité des épigraphistes" and the "cité des anthropologues," see Azoulay 2014). An archetypal study of the kind is obviously Pauline Schmitt Pantel's, La cité au banquet, originally published in 1992 (Schmitt Pantel 2011), in which the author gives a thorough and brilliant study of common meals in Greek poleis; her aim is to analyze practices in different cities, but as usual the latter are subsumed under "the" Greek city, which remains as ever the implicit and overarching concept.

A crucial influence, probably the most crucial for our subject, has been exerted by the socalled spatial turn that has affected the study of the ancient Greek world since the end of the 1980s. The importance of space as being able to shape human action and to be 
shaped by it has been applied to the polis as such and has given rise to a multiple range of territorial studies. A seminal one has been La naissance de la cité grecque by François de Polignac, first published in 1984 (transl. 1995), in which the author explores the links among borders, cults in and outside the urban center, and self-definition of the city. For the last twenty years both archaeologists (through surveys) and historians have devoted a considerable amount of energy to the exploration of civic chorai (e.g., Brunet 1999). The scholars of Greek religion have also extensively contributed to the criticism of the polis framework, as shown by the works of Esther Eidinow (2007), or even more clearly, Julia Kindt (2012). Whereas the former insists on the role played by individuals, the latter shows how the polis-religion model has been and still is productive $(2012,12-35)$, but also how this model doesn't allow one to understand the "embeddedness of Greek religion in the polis," that is, the way religious and sociopolitical structures are linked. As she rightly states, the polis was not the sole level of ritual activities; ethne, for instance, played a very important role. The spatial turn, combined with postcolonial studies and the expanding theories on globalization, has led, from the 2000s onward, to a completely different understanding of the world of Greek cities through the introduction of a series of key concepts: globalization and transnationalism on the one hand, and local interests and localism on the other. According to a modern definition, "global" and "globalization" imply "social, economic, cultural, and demographic processes that take place within nations but also transcend them, such that attention limited to local processes, identities, and units of analysis yields incomplete understanding of the local" (Kearney 1995, 548). The idea of a global Greek space implies a decentered point of view and refers to relatively abstract phenomena (dissemination of ideas, artifacts, skills, etc.), although naturally "globalization" as encompassing the whole globe is not applicable as such during the period under consideration and must be used only as a "heuristic tool" (Vlassopoulos 2013, 21). Probably more easily transposable to the world of Greek poleis is the concept of transnationalism, which "overlaps globalization" but is "anchored in and transcend[s] one or more nation-states" (Kearney 1995, 548). It therefore carries a much stronger political and ideological flavor than globalization and in Greek terms refers to all processes that could be called "transpolitical" as they involve two cities (or more) and their members. One must add here a second dimension, that of federalism, which has had through the construction of Europe in particular a considerable impact on the analysis of political interactions inside all kinds of ancient supra-civic structures. In response to these three dimensions (global, "transpolitical," supra-civic), the "idea of the local" appears to have been "obviously created by supralocal perspectives" (Whitmarsh 2010 , 2). In our case, it cannot be assimilated to the study of Greek communities per se and individually, as has been the case previously, and implies the search for responses to all supra- or transpolitical processes among these communities, which lead to the concept of “(g)locali[z]ation” (Vlassopoulos 2013, 21). 
Following recent trends and developments in the field, this article reconsiders the poleis as an interacting ensemble instead of a simple collection of entities and proposes that the cities, in their practices, were largely interconnected and caught in a double spatial frame of interrelations: one Panhellenic or "transpolitical," horizontal, and operating through a series of networks (apoikiai or colonies, koinai or common practices, Panhellenic events), and the other regional, supra-civic, vertical, and hierarchic (symmachiai or military leagues, koina or confederations, sympoliteiai or fusions of civic communities), both frames implying local responses or adaptations. Naturally the Greek poleis were also connected to other empires and people (the Phoenicians, the Persian Empire, the Etruscans, all the populations labeled as barbarians or local, as if they were more "local" than others, later the Roman Empire, etc.). It would seem therefore legitimate to explore all the relations between Greeks and others in such a (relatively) global ancient world, but it would lead us too far and could be the subject of a book. Also, this kind of link immediately touches on the topic of cultural and ethnic identity of Greeks, a theme that has been thoroughly explored for the last thirty years (Hall 1997, 2002; Malkin 2001; Müller and Veïsse 2014). I have therefore chosen to focus on globalization at the level of the Greek world per se, to see how the cities interacted through multidirectional relationships, trying (although not exhaustively) to provide some fresh and synthetic views on old questions.

\section{Poleis and Networks: A “Small Greek World” (Malkin 2011)}

\section{Archaic Apoikiai and Their Mother Cities}

Peregrine Horden's and Nicholas Purcell's Corrupting Sea (2000) has played a key role in the further development of theories applied to the Mediterranean, as shown by the numerous reactions (e.g., Harris 2005 or Broodbank 2013, who proposes a de-Hellenized perspective on the Mediterranean). The two authors, following a bottom-up perspective, have tried to show both the fragmentation of microregional units throughout this space and the connectivity established by the sea between these units that leads to the idea of a Mediterranean unity in ancient and medieval times. Some of the implications of this seminal book can be found in the work of Irad Malkin, who has in turn developed his own theory about networks established among poleis during the period of archaic colonization in the Mediterranean (Malkin, Constantakopoulou, and Panagopoulou 2009; Malkin 2011). Apart from Malkin, historians have borrowed the concept of networks in a more or less anarchic way from diverse social sciences, especially sociology and geography, and 
one should not forget that these are not objects per se but simply tools to think about previous problems differently (Sourisseau 2012, who adds the idea of fragmentation and flexibility of networks).

That said, "Malkinian" distributed networks show three main characteristics. First, on a spatial and geographical level, is the absence of center or periphery in a network; as put nicely by Malkin $(2005,60)$, "'margins' are an accident either of our meagre sources or of the historical constructs that determine our perspective." The Greek settlements founded on the shores of the Mediterranean ("frogs around the pond" according to Plat., Phaedo 109b) during the eighth to sixth centuries BCE appear to be like fractals (as in fractal physics), each surrounded by its own microregion, but they also form together a constellation of dots linked by lines. The second characteristic, "awareness of affinities," emerges when people are far from one another rather than nearby. Therefore, Greek colonization, through the foundation of hundreds of new polities scattered around the Mediterranean, has been an essential factor in the emergence of a Greek identity, although outside any overarching state (Malkin 2011, 54-64); the sense of shared "commonalities" and the differences perceived between the colonists (apoikoi) and the local populations created what he calls "the Greek wide web of identities" (Malkin 2005, 60). Finally, and this point will allow the quotation of precise cases, these networks can be studied through the traces they have left in the nomima, that is, the identifying features (cults, calendars, institutions) common to the apoikiai and their metropoleis, which Thucydides considers characteristic features of Greek settlements in Sicily:

[3] Gela was founded in common by Antiphemos from Rhodes and Entimos from Crete, who led epoikoi there, in the forty-fifth year after the foundation of Syracuse. The town took its name from the river Gelas, while the place where the citadel now stands, and which was first fortified, is called Lindioi. The nomima which they adopted were Dorian [i.e., common to Rhodians and Cretans]. [4] Near one hundred and eight years after the foundation of Gela, the Geloans founded Acragas (Agrigentum), so called from the river of that name, making Aristonous and Pystilos their founders and giving their own nomima [to the colony]. (6.4.3-4)

One of the best examples of the circulation of nomima is certainly that of the Megarian network, formed between the eighth and fifth centuries BCE (Robu 2014). Megara Nisaia, in mainland Greece, was the mother city of numerous apoikiai located in Sicily, the Propontis, and the Black Sea: Megara Hyblaea in Sicily and its own colony, Selinous; Chalkedôn, Astakos, Byzantion, and Selymbria on the Thracian Bosporus, but also Herakleia Pontike and its apoikiai; and Mesambria, Apollonia, Kallatis, and Tauric Chersonesos on the Black Sea. Selinous had the same gods as Megara Nisaia, with or without the mediation of Megara Hyblaea, as a supplementary oikistes had come directly 
from the original metropolis to cofound (sunkatoikizein) the city (Thuc. 6.4.2). This is a good example of a chain linking grandmother, mother, and daughter cities (Malkin 2005, 70). Among the nomima, Megarian civic subdivisions and the main archai of the metropolis can be found in most of the colonies, such as the eponymous basileus (king) and the five aisimnatai. Calendars and gods would also be common, as can be seen in Milesian (Ionian) colonies: Olbia Pontike, founded in the middle of the sixth century BCE, had kept the twelve Milesian months (Dubois 1996, n99; ca. 450 BCE: graffito inscribed on an Attic skyphos), and Apollo Ietros was its first god imported from the metropolis, while Apollo Delphinios probably came a bit later, in the third quarter of the sixth century BCE. The acme was reached with the emporion of Naukratis in Egypt in the sixth century BCE and the building of the Hellenion, "the greatest and most famous and most visited precinct ... founded jointly by the Ionian cities of Chios, Teos, Phocaea, and Clazomenae, the Dorian cities of Rhodes, Cnidos, Halicarnassos, and Phaselis, and one Aeolian city, Mytilene" (Hdt. 2.178) and administered in common; in Naucratis, the Greeks worshipped the hellenioi theoi, the "Greek gods," not one in particular.

The most fascinating point about these colonial networks is their capacity to be revived much later, until the Hellenistic period: in the third century BCE, Miletos did not hesitate to appeal to the links between it and Kios, a colony founded three centuries earlier on the Propontic coast of Asia minor, to grant citizenship to the Kianoi, as shown by a stela bearing a Milesian decree and referring to the Milesian demos as the ktistès tès apoikias, "the founder of the colony" (Milet. I.3, 141, lines 19-20; 228 BCE according to the ed. pr.).

Colonial networks linking metropoleis and daughter cities from the archaic through the Hellenistic periods through their nomima (shared features), or the reactivation of these, appear therefore as a first symptom of a globalized Greek world.

\section{Common Languages, Common Features: The Koinai of the Classical and Hellenistic Worlds}

Beyond these networks, one of the most important features of the Greek world has been its capacity to produce different kinds of "commonalities" that clearly transcend the level of the polis or colonial networks and could be called koinai, as in koinè meaning the common language that imposed itself during the Hellenistic period.

The story of the linguistic koinè is a very complicated one, and its adoption should not be seen as linear. One should first distinguish between the adoption of alphabetical writing, borrowed from the Phoenicians at the beginning of the eighth century BCE, and the use 
of different regional dialects. The story of writing is at first one of a diversity of alphabets, although the principle was a common one. These archaic and classical scripts are all "local versions of the same alphabet" (Jeffery 1982, 822, 1990), which is a good way to show how the global and the local can be articulated. The Ionic version finally won, in Attica officially in 403-402 BCE, although inscriptions show that such a reform did not produce immediate effects (and could be anticipated), and elsewhere during the fourth century BCE. The story of dialects is a different one (Woodard 1997). The so-called koinè resulted from the evolution and expansion of the most prestigious and influential of the dialects, the ionized Attic, outside Attica from the fourth century BCE (López Eire 1996). The propagation of this "super-dialect" certainly participated in the construction of a global Greek world, but it calls for two observations. First, this process, far from being as neutral as one might think, appears to have been highly political, as ionized Attic was adopted as an official language and diffused by the Macedonian chancellery and was later used by the Romans as a tool to communicate with the eastern part of the empire. Also, its existence does not mean that dialects disappeared. Regional, and even local, dialects remained vivid until the mid-second century BCE in some regions. The koinè was not the only one of its kind; there were other koinai, especially in western and northern Greece, which transcended civic and regional borders and can be seen as competing with the ionized Attic and resisting its pervasive influence. In Boeotia, for instance, which is not an isolated case, the common idiom did not disappear at the same time as the confederacy, in 172-171 BCE, when the Romans decided to send the Boiotoi back to a life kata polin, "everyone in their own city" (Plb. 27.1). Linguistic globalization does not imply a complete homogenization of practices, and it encountered unavoidable resistance at the local level.

Another aspect of the "koineization" (I borrow the word from Minon 2014) of the Hellenistic world is common political practices. Although democracy was not the sole political regime, democratic institutions were largely widespread at that time and allowed the cities to establish links in a multidirectional manner. One of the best examples is the use of foreign judges in Asia Minor and mainland Greece (Cassayre 2010, 127-177). Through this procedure, a city (A) could decide to trust another one (B) to have internal cases judged by a mobile court, often comprising one to five judges and a secretary who would come to city A, after the latter had sent an embassy led by a dikastagôgos, an official in charge of escorting these foreign dikastai. At the end of the third and the beginning of the second centuries BCE, the city of Antioch on the Maeander sent for foreign judges to the cities of Magnesia on the Maeander and Erythrai, as shown by two Antiochean decrees honoring these judges (I.Magnesia 90 and I.Erythrai I, 117). The links between Antioch and Magnesia rest on geographic proximity and philia, "friendship," mentioned in the decree, although the latter was an old city and the former a Seleucid foundation (Cohen 1995, 250-253). This appeal to foreign courts might be a sign of a 
temporary crisis, but certainly does not imply a total failure of the civic judicial systems. It means at least that there existed a unity of Greek law, a juristic koinè among all these poleis (Gagarin 2005; Mélèze-Modrzejewski 2011), whatever the role Hellenistic kings might have played in encouraging these processes.

Hellenistic poleis were also linked in a very dense network through the granting of various privileges to individuals or whole communities, clearly a "transpolitical" process as well. The bestowal of philanthrôpa, "privileges," mentioned in honorific decrees, has long been taken to mean a simple rewarding gesture toward euergetai, benefactors, and has been far less commented upon than the content of the benefactions. Through these privileges the cities were allowing foreigners, whose status would not be modified as such, to exercise one or more legal capacities outside their own little patris,

"homeland" (Müller 2014a; on proxenia see Mack 2015). Among hundreds of this kind, a decree of Oropos, a city located on the border of Attica and Boeotia, granted "standard" honors to an Athenian named Aristeides around 290-260 BCE: proxenia for him and his descendants, that is, "the right to be a proxenos" looking after Oropian interests at home; enktesis, "the right to acquire land and a house"; the isoteleia, "the right to pay the same taxes as citizens"; asylia, "security for goods"; asphaleia, "personal security," in times of war and in times of peace, on land and at sea; as well as all of the other privileges granted to other proxenoi and euergetai (I.Oropos 26). Should the honorand choose to use these privileges, it would create a micro-link between Athens and Oropos. Among all these links, the economic ones were primordial, through taxation regulations. The bestowal of ateleia, "exemption from taxes," in particular has been recognized as a tool that could be used to attract emporoi, "merchants," and the goods they had to sell; this exemption usually concerned commercial taxes, for instance pentēkostē, the " $2 \%$ tax on importation and exportation," in Athens and other ports, and granting it had obvious financial and economic implications (Oliver 2007, 30-37). In the fourth century BCE, according to Demosthenes (Against Leptines [20], 30-33), the law passed in 356 by Leptines abolishing all immunities would directly harm Leukôn, the king of the Bosporan kingdom: the latter had ateleia in Athens, which means that every ship arriving at the Athenian emporion in the name of the king would get the exemption from pentèkostè. Yet the grain from Leukôn and his kingdom was vital for the Athenians, who were importing huge quantities from the northern Black Sea, up to 400.000 medimnoi a year (20.32). Hence the use by Demosthenes of the word synthēkai, "treaties," to designate the content of the stelae bearing the decrees in honor of the Spartocid king (20.37), which corroborates Aristotle's saying that one can make synthēkai "about importations" (Politics 3.5.11, 1280a-b; Müller 2010, 236-241). 
A more complicated case is the granting of politeia, "citizenship," regularly mentioned among other philanthrôpa. In approximately 340-330 BCE, a decree from Olbia Pontike granted the following to two Athenians: proxenia, politeia, ateleia, and so forth, as well as the "right to enter and leave the port." Politeia here obviously means the right to participate in the political life of the city through the krisis, "right to judge," and the arche, "right to hold a charge." But it raises the question of residence, as such participation seems difficult without it. Should this person choose to live in Olbia, would he lose his original citizenship? That has long been taken for granted, but no text explicitly states that one had to give up one citizenship to activate another one, which means that multiple citizenships were highly probable, although not that frequent (or frequently used) even in Hellenistic times, with the original politeia being suspended. The question of multiple citizenships must be raised also in the case of collective bestowals of citizenship on a whole community with or without reciprocity. In an inscription found in Miletos, a city accustomed to this practice, and probably dated in the third century BCE (Milet. I, 3, 136; Rhodes and Osborne 2003, 93), Milesian citizens are given collectively different rights in Olbia Pontike (and vice versa), including the capacity to hold charges. But the text forbids the granting of ateleia to "[the Milesians] who exercise politeia in another city [other than Miletos and Olbia] and participate there in the offices and the courts" (lines 18-20). The grant of politeia does not imply here a massive transfer of people, but suggests that some individuals would activate their rights using collective politeia decrees and end up living in a city linked with Miletos without loosing their original citizenship (Müller 2015).

Men acquiring politeia in a great number of polities would deserve to be called, in a way, kosmopolitai, "citizens of the world" (Konstan 2009, 475). The most ancient collection of citizenships is that of Nikomedes of Kos, a very important collaborator of Antigonos the one-eyed at the end of the fourth century BCE, for whom were erected in his fatherland two stelae bearing more than thirty decrees (among which at least six granted politeia) voted in his honor by Aegean and micrasiatic cities (IG XII, 4.1, 129-130; Savalli-Lestrade 2012, 44-45). Nikomedes did not of course reach the level attained by Markos Aurelios Asklepiades a few centuries later, around $200 \mathrm{CE}$, when this pankration athlete set up an inscription in Rome recording that he was "a citizen of Alexandria, Hermopolis, and Puteoli; a member of the boule, 'City Council,' of Naples, Elis and Athens; and also a citizen and member of the Council of many other cities" (Inscriptiones Graecae Urbis Romae I.240, lines 4-10; Konstan 2009, 475). This kind of cosmopolitanism is quite different from that professed by Diogenes in the fourth century BCE, who was called (or was calling himself?) kosmopolitès, according to Diogenes Laertius (Lives of the Philosophers 6.63). Either the Cynic thinker was in a negative way indicating that he did not belong to any particular polis and was a foreigner everywhere, a way to show his 
rejection of society, or, in a positive perspective more often associated with the Stoics, the word would imply that the kosmos, taken as "the natural world" and "the international community of wise and good" (Konstan 2009, 476), could be conceived as a polis, a constant pattern of thinking among the Greeks, as we have seen.

So the Greek cities from the fourth to the first centuries BCE appear to have created a very tight network of multiple micro-links. But in any case, cosmopolitanism appears to have been the privilege of a happy few, an elite phenomenon.

\section{Panhellenic Festivals}

Finally, one must add religious and cultic networks, probably the best known, although there are not very many synthetic studies (Kyle 2007; Christesen and Kyle 2013). Thanks to the common pantheons of cities and beyond any local or regional differences, athletes could go from one athletic or musical agon, "festival," to another. This vast movement started in the archaic period, as we know from Pindar's epinician odes, which celebrate and commemorate successes of athletes in diverse athletic contests, such as in $464 \mathrm{BCE}$ the boxer Diagoras of Rhodes (Ol. 7) and Xenophon of Corinth, a specialist in the foot race and pentathlon (Ol.13). The victor or his family commissioned the poet to write such works. There were four great festivals, belonging to the so-called periodos, "circuit." The first and most prestigious, the Olympia, was an athletic competition in honor of Zeus that took place every four years (therefore a penteteric event according to the Greeks, who were counting the five years of such a time span) in Olympia on the territory of the city of Elis in the Peloponnesus and had emerged slowly from a local agonistic tradition at the beginning of the seventh century BCE; the Olympics were a typically Greek activity, as they were exclusively reserved to Greek men and boys, at least those who could be proved proper members of their polis (Philostr., Gym. 25), what has been rightly called the "oily trinity of free, Greek, and male" (Kyle 2007, 118). The judges, although called hellanodikai, "judges of the Hellenes" (Paus. 6.24.3), were Eleans, as the city of the latter was in charge of the organization. The Olympics were "so successful that they became the model for other Panhellenic crown games" (Kyle 2007, 110), from the beginning of the sixth century BCE. These were the Pythia at Delphi in honor of Apollo, but controlled by the religious institution called the Amphictyony (Lefèvre 1998); the Isthmia at the sanctuary of Poseidon at the isthmus, controlled by the wealthy Corinth, two competitions both musical and athletic; and finally the Nemeia, which took place either at the sanctuary of Zeus at Nemeia or in Argos, an athletic agon until the Hellenistic period. These festivals were announced by theoroi, "sacred ambassadors," all over the Greek world, who would go from one place to another in a defined region under the leadership of an architheōros and be the lines connecting the dots on the cultic map of the Greek 
world. The festivals were the occasion of an ekecheiria, a "sacred truce," proclaimed by heralds, but the aim was only to forbid the entry of armies onto sacred territories and ensure safe passage to and from the sanctuary for the athletes. All these measures certainly never prevented any wars between Greeks, but they favored the possibility for them to gather more or less safely at the sanctuaries, as all interstate events were the occasion for pilgrims and visitors of big panegyreis, "fairs," that would serve beyond any religious purpose for the economic exchange of goods not always available in the local territory (Chandezon 2000).

The four main festivals, however, were not the only ones, and the Greeks had dozens of local or regional competitions in which nonlocal people could participate, such as the Asklepieia in Cos or the Ptoia in Boeotian Akraiphia in honor of Apollo Ptoios. These festivals are well attested during the Hellenistic period, but probably had appeared earlier during the classical period, even if they are less documented. In connection with these numerous events, the theōroi's mission was sometimes to ask for asylia, "territorial inviolability," for the sanctuaries and sometimes the cities where the competitions took place, so that safety would be ensured for the participants (Rigsby 1996); the asylia requests cover the whole Hellenistic period from the 260s till the age of Tiberius and are one of the best examples of what could be called "sacred connectivity," although the agenda beyond these processes was also highly political. The contests in these competitions could be athletic and/or musical, such as the Pythia, which had both, so that athletes are not the only participants recorded on the long victors' lists left to us on inscriptions. From the third century BCE, one observes an intensification of artistic mobility, with the creation of guilds of mobile artists called the technitai, "specialists of a techne," which traveled all around Greece (Le Guen 2001). Four companies are known for Athens, Isthmus and Nemeia, Ionia and Hellespont, and Egypt and Cyprus. Their members were free men, working under contracts and providing their services as artists for remuneration in local or international religious events. They were ruled by nomoi, "laws," and had magistrates, just like poleis or associations. In a decree passed by the Delphic Amphictiony around 225 BCE (Corpus des Inscriptions de Delphes IV, 70), whose role was also to protect the Dionysiac artists at a regional level, the technitai of the Isthmus and Nemeia, at their request, were granted asphaleia, "personal security," and individual asylia, "prohibition to seize their property," to go safely to the Theban sanctuary of Dionysos Kadmeios for the trieteric ("every other years") festival; the Boeotian city of Thebes was granted the asylia, "inviolability," for its sanctuary, and the sacred truce was said to be looked after by the magistrates of the Amphictiony.

This section has illustrated how the movement of people, individuals coming from and generally representing their cities, could create dense networks throughout the Greek world. Such a process definitely started in the archaic period, even if for that time people 
are less easy to identify than the traces they left in the material or institutional record. It continued during classical times and intensified after Alexander's death. Hellenistic poleis from both sides of the Aegean and far beyond started to express the feeling that they belonged to a common, globalized world, using the concepts of sungeneia "kinship" and oikeiotès "intimacy," which best embody such an ideology of linkage (Gehrke 2003).

\section{Supra-civic Structures}

The mention of the Amphictyony in the previous section leads us to a second level of interactions among poleis, the regional one, through the supra-civic structures. Under this term are gathered all institutional forms that went beyond a purely local polis structure and acted in a highly hierarchical way, contrary to the networks previously evoked: symmachiai, "military alliances"; koina, meaning confederacies; and sympoliteiai or sunoikismoi, "fusions of polities or territories." These structures are very complex and less studied than the Panhellenic networks.

\section{Symmachiai or Military Alliances}

The first type of supra-civic structure, although looser than the other ones, is the symmachia, a "military alliance," often called a league by modern historians and placed under the domination of a hegemon, a military "leader," which could be a city or a king. The membership required military and/or financial contributions. Various common institutions (e.g., the Hellenistic synedrion or "council") are known in the period under consideration. The word symmachia was used in the fifth century BCE (Buraselis 2003) and included structures much bigger in size than any koinon or sympoliteia. The archaic and classical alliances are well known: the Peloponnesian League, the Delian League, and its fourth-century revival. Later on, one of the biggest, after 338-337 BCE, was the League of Corinth, based on the principle of the koine eirene, the "common peace," under the hegemony of Philip the second and known through the oath sworn by new members $\left(I G I^{3}, 1,318\right)$. One interesting point about the latter is that some members were themselves small confederacies, such as the Locrians or the Phokians. Demetrios Poliorketes later revived this huge league in 302 to get support from other Greeks (IG $\mathrm{IV}^{2}, 1$, 68; Will 1979, 77-79), and Antigonos Dosôn was in turn "established hegemôn of all allies" (Plb. 2.54.4; Will 1979, 389-401) in the so-called Hellenic League in 224 with the Achaeans. This time the members of the league were all confederacies-Phokians, 
Boeotians, Acarnanians, and so forth-and their victory at the battle of Sellasia against the Spartans in 222 BCE was commemorated in Delos (IG XI, 4, 1097). But these structures appear more as diplomatic instruments in the hands of their hegemon than as anything federal, contrary to the so-called koina.

\section{Koina or Confederacies}

The fact that the Greeks had tended throughout their history to create bigger political (and not only military or diplomatic) entities, such as confederacies, has long been noticed and analyzed. Jakob Larsen's Greek Federal States, published in 1968, follows a historiographical tradition going back to the nineteenth century and remains the most comprehensive reference on the topic. Yet a vast range of studies has flourished in the last thirty years about different regions (e.g., Achaia, Boeotia), exploring for a large part global problems: the link between koinon and ethnos through the question of identity (Morgan 2003), religious issues concerning the origins of confederations and the common activities of their members (Mackil 2013), and the recognition (or not) of archaic ethne as formal political organizations (Hall 1997, 2002). But the interactions among poleis members inside a koinon have not yet attracted the same attention, and I therefore concentrate on this aspect.

One of the most recent trends in the study of koina focuses on their territory and spatial distribution. Boeotia provides here an excellent case study. In a papyrus known as the Hellenica Oxyrhynchia (Chambers 1993), an unknown historian gives an account of the years 396-394 BCE in Greece at the time of the Spartan king Agesilaus and some invaluable details (§19) about the organization of the first Boeotian confederacy (447/446-386). The latter, called ethnos as a synonym of koinon, comprises some twenty poleis, divided into smaller units called chôria, "villages," but the most original feature was the existence, between the head and the cities, of eleven merè, "districts," serving as a base for the proportional distribution of archai, "magistrates," in the federal bodies. For instance, among the eleven Boiotarchs, "chiefs of Boeotia," four were reserved to the Theban district, including two for Thebes itself and two for Plataiai and its satellite villages. Tanagra had one Boiotarch, and Haliartos, Lebadeia, and Coroneia shared one, appointed in turn by each polis. The same principle prevailed in the appointment of bouleutai, "members of the Council," or dikastai, "judges"; the sending of troops, hoplitai, "infantry soldiers," and hippeis, "horsemen"; or the paying of eisphorai, "taxes." But the federal institutions themselves appear to have been replicas of civic ones: each polis had four boulai, that is, four sections of a bigger council, operating in turn in an oligarchic system; so did the koinon with 660 bouleutai, that is, 60 for one meros, "district." The 
same phenomenon can be observed in the Hellenistic confederacy in the third century BCE, where seven districts served the same purposes, as recently detected through the ethnics of magistrates mentioned in federal dedications (e.g., IG VII, 2723 [from the sanctuary of Apollo Ptoios in Akraiphia]; Knoepfler 2002; Müller 2011), although the system was much more democratic at that time. So here lies the paradox: Boeotia had a very original and elaborate conception of spatial distribution of power at the level of the koinon, but could not conceive of any board of magistrates or federal component that would not be on the model of the polis. The same conception can be observed for the Hellenistic Achaian koinon that covered most of the Peloponnesus and could be compared, according to Polybius (Histories 2, 37, 11), to a big city if it had common walls.

Koina appear as highly hierarchical structures, in which the supra-civic level could exert pressures on the members, although the latter would remain autonomous entities at a local level with their own institutions. In the Hellenistic Achaian koinon, for instance, membership was allowed only to individual poleis and prohibited to any grouping of cities placed under a hegemonic leader polis (Rizakis 2008, 276-277). Membership was established through a homologia, "convention" (e.g., with Orchomenos of Arcadia, IG V, 2, 344), and a strong vertical relationship was promoted between the federal and the civic levels that could create deep conflicts, such as the troubles with Sparta when it was forced to join the league in 192 BCE and then endured very harsh treatment (Plut., Phil. 16.2-5). But horizontal cooperation between cities was facilitated through the rights granted de facto to new members in the whole territory of the koinon, such as free circulation, intermarriage, or enktesis, the "right to hold property," which helped to eliminate rivalries in the Peloponnesus. In Boeotia there was no proxeny granted by city members to individuals inside the koinon before its dissolution by the Romans in 172-171 BCE; there was no need for "internal proxenoi" because of the federal structure. The same can be said about foreign judges, an institution that did not exist in this area as long as there was a koinon. But cities had some rights of their own, such as the capacity to grant proxenia to members of political communities outside the confederacy, a form of autonomy in their foreign policy. Boeotian Orchomenos, inter alia, gave proxenia to a Locrian from Amphissa in the last quarter of the third century BCE (Roesch 1989, 222). When a civic decision had consequences at the federal level, the authorization of the koinon could be required before the granting of enktesis or politeia, "citizenship," as seems to have been the case in the Etolian confederacy when Naupaktos gave both privileges to the Keians (Syll. ${ }^{3}$ 522, I-III; ca. 220 BCE).

The members of a koinon were poleis, but this had consequences for individuals who were part of it, sharing a common citizenship best expressed through the use of a federal ethnic. Boeotians, especially outside of Boeotia, were called Boiōtoi. In Achaia, the 
federal ethnic was given through the homologia (IG V, 2, 344, line 12) and followed either by the local ethnic or the name of the polis; in 399-398 BCE the Athenians inscribed as proxenos and euergetes of the city Aristeas Achaios Aigieus, that is, Achaean from Aigion (IG II ${ }^{2}, 13$ with SEG 40,54). This double naming probably goes back to the end of the fifth century BCE (Rizakis 2012, 25-28). The access to federal citizenship is best known and studied for the Achaian confederacy. It could be obtained by foreigners indirectly through the granting of any civic politeia that automatically led to the federal one. It could also be obtained thanks to the integration of a whole city by the koinon through the homologia previously mentioned. That raises the question of whether in this case the granting of federal politeia would give access to all the local ones and to the rights attached to them. The problem was the same for the granting by koina of privileges to foreigners that would affect the civic level, such as the enktesis, which means a transgression of the rights of the poleis over their own territories. For Boeotia, we know of numerous federal decrees, such as the one for Ophelas of Amphipolis (I.Oropos 21; 237-227 BCE), in which he was given enktesis, isoteleia, "the right to pay the same taxes (as Boeotians), and asphaleia, "personal security," obviously potentially valid in the whole territory. The rights implied by the politeia normally necessitated legal registration of the beneficiary, but one wonders if other privileges (especially those linked with mobility and circulation) required such a procedure or could be used directly. In the case of politeia (and enktesis?), the honorand, if willing to activate his right, would either be allocated by the koinon to a city to settle in, such as in Triphylia in the Peloponnesus at the beginning of the fourth century BCE (SEG 35, 389), or choose it, as in Acarnania in the third century BCE (IG IX, 1, 445).

The links established between cities were sometimes so tight that even after the disappearance of a koinon, they could be expressed through common religious activities consciously organized as memorial ones. In Boiotian Akraiphia, in the late second century BCE, that is well after the dissolution of the koinon in 172-171, the festival in honor of Apollo Ptoios was reorganized as penteteric and conceived as a Pamboeotian one, meant to reactivate a form of collective identity, based explicitly on sungeneia, "kinship" (e.g., IG VII, 4139; Müller 2014b, 130-136). But such terminology could also be used to designate the links between two or more entities linked by sympoliteia.

\section{Sympoliteiai and Synoikismoi}

The word sympoliteia expresses the idea of a "shared citizenship" between different political entities. It therefore applies both to the politeia at a federal level in koina and to the politeia that results from the merging of two or more communities. These two levels 
are in general distinguished as such by modern historians, although they probably don't differ that much and need to be taken together. Sympoliteia is often taken, and rightly so, with synoikismos, which refers to a "community of residence" and therefore means the "merging of territories." One could say that the synoikismos is the concrete and territorial version of the sympoliteia. And the sources show that a synoikismos can refer to what we call a sympoliteia, as the latter word is not always attested for all cases. In the classical period, the verb sympoliteuein, "to participate in a sympoliteia," is the only one attested, for instance about the Olynthians and the cities of the Chalkidian League in Xenophon (Hellenika 5.2.12). In the 380s the Olynthians, who were getting powerful in Thrace, wanted to sympoliteuein, "to have a common political organisation" with a lot of cities dominated by it, while on the other side, people from Acanthos or Apollonia wished to stay autopolitai, "having their own city," and therefore appealed to Sparta against Olynthos (Buraselis 2003). This Olynthian way of sympoliteuein was double-sided. It was not so different from a symmachia, as the polis appeared as a hegemon, but it also looked like a koinon, as Olynthos was also the "capital" of the confederacy; most monetary series show the name of the Chalkidians, while some earlier ones have the name of the Olynthians (Psoma 2001; Buraselis 2003, 41). Obviously modern categories that distinguish neatly among these political types are not always relevant.

The same remark applies to sympoliteia meaning the fusion of different civic communities, called by some historians bilateral sympoliteiai (Pascual 2007), although there could be more than two communities. The noun itself was used only in the Hellenistic period, but the phenomenon started at the end of the fifth century BCE with one of the biggest and most successful political and territorial reorganizations of the classical period: the birth of the Rhodian state. The polis of Rhodes emerged in 408-407 after a long and complex process of cooperation among the three previous insular cities, Lindos, Ialysos, and Kamiros. The newly founded city of Rhodes became the capital of a new state covering the whole island, which would become one of the most powerful micro-empires of the Hellenistic period (Gabrielsen 2000). The later sources call this transformation not a sympoliteia, but a metoikismos, "transfer of population" (Diod. 13.75.1), or a synoikismos, "merging of territories" (Strab. 14.2.10). Obviously not all the population was transferred to the settlement, as previous communities were maintained, especially in their religious role. Lindos hosted a very important sanctuary of Athena Lindia and was still called a polis after 408-407, just like Ialysos and Kamiros, which makes them dependent poleis in Hansen's typology of dependency (Hansen and Nielsen 2004, 87n10 and 1196-1210), but also phylai, "tribes," of the bigger structure. This sunoikismos appears as a probable model for other cases, such as Cos, whose poleis merged in 366-365 BCE through a metoikismos (Strab. 14.2.19, who uses the verb metoikeô, "change residence"; Hansen and Nielsen 2004, n497). 
These two cases were followed by numerous others, both in continental Greece and Asia Minor, where the Rhodian model might have been influential again (Reger 2004). One example is enough here, although there was no real standard procedure, and all the cases stand apart. One of the most telling stories is that of Carian Pidasa, which was finally swallowed by the big Milesian polis at the very beginning of the second century BCE. The story starts at the end of the fourth century BCE (ca. 323-313) under the probable influence of the local satrap Asandros, with the physical and political incorporation of Pidasa into the city of Latmos (later refounded as Herakleia Latmos), known from a treaty containing very precise clauses (SEG 47,1563, with the addenda of SEG 53, 1198; Van Bremen 2003, 313-317). The most original and striking clause is the one requiring that for the six years following the treaty, Pidaseans were supposed to marry only people from Latmos, and vice versa. Pidaseans (though not all?) were meant to move from their old territory and settle in Latmos, where the Latmians had to provide them with houses, while the new citizens were allowed to build houses where they wanted on the public land of their new polis. Pidaseans and Latmians together were dispatched by lot into a new tribe and the rest of the Pidaseans into the three preexisting Latmian tribes. Public finances and patrimony were united, and all Latmians and Pidaseans were granted equal access to public charges. As can be seen, everything was done to prevent as much as possible the local re-creation of any Pidasean identity. It's difficult to tell if the operation was a success at the time of the treaty, but obviously such a process was not irreversible, as Pidasa was again identified as a polis at the beginning of the third century BCE. The next process was the amalgamation with Miletos (Milet. I, 3, 149), which put an end to the autonomous existence of the smaller city, probably in 187-186 BCE. This time the Pidaseans themselves took the initiative in the process (as rightly argued by Gauthier 2001), to be placed under the protection of their powerful neighbor against Herakleia Latmos, their old rival. Most clauses are to the advantage of Miletos, and even if Pidasa certainly became a subdivision of the city (maybe a deme), it partially retained its own identity and formed with Miletos a community both united with and different from it. Milesians gained military and economic advantages in the operation: they built a new road on Pidasean territory, rebuilt the walls, and sent a garrison there. In the meantime, Pidaseans were allowed to stay on their chôra (not in the urban center) and cultivate it, although 390 of them were provided with places to stay in Miletos, following a predictable and partial exile of the population; they got some reductions on taxes, some temporarily and others permanently, and seem to have been incorporated as a group into the Milesian civic body. This example is a good way to demonstrate what "local" and localism could mean to Greek communities in a period (the Hellenistic times) prone to creating big entities, one of the symptoms of globalizing tendencies in the Greek world. 


\section{Localism and the City}

\section{A Permanent Tension}

The idea that poleis were linked together in different types of networks does not mean that every member of every community was permanently connected with the rest of the Greek world. Connectivity is used here as a tool to argue against a certain static conception of the city. But it should not be misleading. The processes dealt with above are mostly elite phenomena: benefactors, artists, athletes, philosophers, ambassadors, theōroi, and seers are in general members of the wealthy part of society and serve as "mediating figures" (Whitmarsh 2010,12) or as "connectors between the dots on the map" in network terms. As Whitmarsh notes about the Roman Empire, "cosmopolitan intellectuals do not float above locality, rather they shuttle between different locales, mediating between the local and the global" $(2010,13)$, a sentence that could easily be applied to the previous periods. An extreme case of movement and therefore connection between 403 and 399 BCE is Xenophon's army in the Anabasis: the Ten-Thousand are a melting pot of mercenaries coming from all over the Greek world and form a kind of wandering polis, an improvised community shaping its identity as it moves on (Ma 2004, 342). These soldiers are eager to go back home to Hellas, whatever "home" can be, although Xenophon suggests they should settle down (Anab. 5. 6, 15-18; 6, 4, 1-6), foreshadowing the mixed Hellenistic colonies. This army typically embodies the tension felt by any Greek community between the inside and the outside, the local and the global, the civic and the supra-civic, and shows that localism and the idea of the local are a byproduct of globalism, a reaction to connectivity.

\section{Civic Ideology and Local Identity: The Dream of the Island}

I have already quoted Plato in the Laws, for whom the ideal city, that of the Magnètai, is a sort of island in another island (Crete); I call that the dream of insularity, so typical of polis ideology. Further in the same essay, he describes in detail how a city could be as closed as possible (Laws 12.949e-53e). In a famous text (Pol. 7.1326b), Aristotle in turn explains the ideal location for an urban center, with a thorough discussion about the advantages and drawbacks of being next to an emporion, a "port"; the philosopher therefore allows his reader to understand what a threat foreigners and emporoi could represent for a city in the mind of his contemporaries. And he seems to be a follower of Plato when he expresses the idea that autarkeia, "autarky," is for a city the telos kai 
beltiston, "the goal and the best thing" (Pol.1.1253a). But his conception of autarkeia is much more open than has been thought for a long time (Bresson 2000). This word does not imply a complete isolation and self-sufficiency of the polis; it includes maritime exchanges to make sure that the city can be properly fed, hence the necessity of a possible communication with the sea. Yet localism and the maintaining of local identity remain fundamental. The political expression of it is the permanent claim for autonomy and eleutheria, "freedom." In the treaty concluded between Athens and Chios in 384-383 BCE (Rhodes and Osborne 2003, n20), one of the main conditions was that the Chians, within the framework of the Peace of Antalkidas (386 BCE), would be allies "on terms of freedom and autonomy" (1. 20-21) to prevent any aggressive attempt from Athens, as was the case in the fifth-century symmachia. Eleutheria and autonomia then became a leitmotif of the political life of Greek cities: although these words had quite a restricted, or at least flexible, meaning in the Hellenistic period, for instance, when lots of poleis were incorporated (with diverse statuses) into the kingdoms, the former never stopped fighting for such privileges. As an honorific decree for a phrourarchos from Priene, "commandant of a garrison," nicely states, "nothing is more important for the Greeks than eleutheria" (IK 69.1 [Priene], 25, lines 18-20; second half of the third century BCE). Between 203 and 190 BCE, the city of Teos in Asia Minor was proud to show the world, through the engraving of inscriptions, that it had received important privileges from a Seleucid king called Antiochos (either III or his son), as stipulated in a royal letter in which the key word appears to be eleutheria, although the inscription is badly mutilated (Ma 1999, epigraphical dossier n19, C, 1. 5).

\section{Ideology in Practice: Control over Civic Bodies and Borders}

The story of Greek poleis was therefore one of constant control. Civic bodies were highly protected against any intrusion, as shown by Athenian legislation from the mid-fifth century onward (Kamen 2013). The Pericles "law on citizenship" restricted the title of citizen to people born from two astoi, that is, a citizen and the daughter of a citizen (Aristot., Ath. Pol. 26.4; Plut., Per. 37.2-5). This process occurred in the fourth century $\mathrm{BCE}$, with harsh penalties inflicted on people trying to transgress the law, which seems to have happened not rarely: slavery for foreigners marrying Athenians; atimia, "civic degradation," and seizure of goods for Athenians giving in marriage foreign girls as their own (Dem., Against Neaira [59], 16 and 52). During the classical and Hellenistic periods, the granting of politeia to foreigners implied that they would activate it through a proper inscription in the relevant bodies of the city (tribe, deme, phratry: e.g., $I G \mathrm{II}^{2}, 856$ ), if they wished to participate in political and judicial activity. As we have seen, that did not exclude dual citizenship, but links between cities were not necessarily established 
through politeia. Until the end of the Hellenistic period, cities remained very strict in maintaining statutory boundaries between citizens, foreigners (or free people without political rights), and slaves, as can be observed in some inscriptions recording decisions of politography, "enrol[1]ment of new citizens," in emergency cases. A good example is Pergamon in 133 BCE after the death of the last king, Attalos III (OGIS 338), when the city upgraded resident foreigners to citizens and some slaves to resident foreigners. Status is not a matter of self-definition, and the city was the only one to have the right to "move the lines," so to speak.

Cities also controlled movements of people and especially foreigners. The control of goods is easy to link with the necessities of taxation, but the control of people is also deeply rooted in the idea that these foreigners could be trouble for the local order. Every city had its own arsenal of laws to control mobility, and the image of free circulation in and out of Greek cities must be seriously revised (Bresson 2007). One of the biggest difficulties for a foreigner would have been to prove his identity, although different kinds of documents already existed on papyri, such as the symbolon, a written document stamped with a seal. The control exerted by cities over foreigners in ports can be read in the granting of privileges linked with the emporion, "port," such as the right to get in and out, the right to import and export, and the ateleia, "exemption from taxes." In Athens and also in other cities where the same terminology is attested, once the foreigner became a resident, he would then change from xenos, "foreigner," to metoikos, "resident foreigner"; the metoikia was quite a comfortable status for citizens of other cities but also one implying obligations, such as having a prostatēs, "patron"; paying a special tax, the metoikion; and sometimes having to pay the same taxes and accomplish the same military duties as a citizen, without the right of political participation.

A last essential way for the cities to express their localism through control was to keep their borders as intact as possible. Wars over borders and territories were incredibly numerous and persistent in the world of Greek poleis until the Roman Empire. The protection of the chöra turned into an obsession, as one can see in the epigraphic documentation. The smallest and most obscure cities would be aware of their limits and establish them precisely if and where needed, hence the presence of horoi, "boundary stones," in the Greek countryside. In the third century BCE, the Boeotian cities of Kopai and Akraiphia were both members of the Boeotian koinon, and in the same district, but they probably had a territorial conflict: limits were established under the supervision of the confederacy (a useful tool here) and published through the engraving on a big rock still visible in situ between the two territories (IG VII, 2792). Such horoi never delineate any territory in its entirety, however, as the notion of continuous boundaries does not apply to Greek poleis. A metaphorical way to fight for one's local civic identity was also to compete through the wealth of offerings, especially at interstate sanctuaries (Delphi, 
Olympia), which would host treasuries, that is, small buildings shaped as temples and containing these offerings. In this respect, these sanctuaries can be seen as mediating "between different levels [local and universal according to the author] of Greek identity by setting them into a spatial relationship with each other" (Kindt 2012, 154). But even the most Panhellenic events, such as the Olympia, were the occasion of "parochial patriotism" (Kyle 2007, 130), and Eleans had to fight against greedy neighbors to maintain control of their sanctuary.

\section{Conclusion: Parochial versus (G)local?}

"Parochial": the word has launched a new trend in the study of Greek cities, that of localism, sometimes called "parochialism," that echoes contemporary interests in local life and participative democracy. After two decades of networks and exchange analysis, one should now look at the "parochial polis," which "turns to the flip side of hyperconnectivity" (Beck 2015). According to some historians, most poleis gave an "autoreferential and sociocentric" response to the changes in their political and cultural environment. They were more interested in their local tastes, habits, and events (identity and self-representation) than in whatever happened beyond their borders; hence the importance, for instance, of local historians such as Memnon of Herakleia Pontike, who wrote a history of his city in the second century $\mathrm{AD}$, itself based on local historians of the classical and Hellenistic periods (Dana 2011, 243-246), or, less known, Syriskos of Tauric Chersonesos, honored in a third-century BCE decree for having written about the epiphanies of the local goddess Parthenos (Müller 2010, 378-379). This statement is based on the idea that communication was far less extended in ancient Greek societies than one would have thought after so much focus on globalization.

The importance of localism in understanding Greek societies is undeniable, but the previous perspective runs the risk of going back to a Platonic view of civic insularity (which is a philosophical model created to give birth to the ideal polis) and misses in a naive way the "big picture" that explains so much about local agendas. Syriskos did not only celebrate the Parthenos, but mostly talked and wrote about the good relations between his city and the Bosporan kings or other poleis, as one is told in the decree. If localism is a key concept, it cannot imply that one simply goes back to a monographic conception of the history of Greek poleis. Localism is certainly better understood through the neologism of $(\mathrm{g})$ localism, a much more positive and useful tool than "parochialism" and encompassing "the variety of ways in which local communities and cultures adopt and adapt the global koine" (Vlassopoulos 2013, 21). A very good example is the way civic societies absorbed and incorporated the idea of Roman domination through the creation 
of a cult for the goddess Roma in the second century BCE, then for some generals in the late republic, and finally for the emperors, following the very Greek tradition of the cult of Hellenistic rulers. Wherever the initiatives lie, such behaviors were responses to the imperium Romanum, and these very local manifestations would have enhanced "the sense of the interconnectedness of the empire" for "those who viewed the monuments and participated in the festivals" (Whitmarsh 2010, 7). Global models could also be rejected; that much is true. As we have seen, resistance to the koineization of the Greek language is a good example of what localism could mean, until the very end of the second century BCE. The use of Boeotian dialect in some late Hellenistic inscriptions cannot be understood as the pragmatic use of their ancestral language by remote and mountainous communities; it had a specific ideological flavor that would remain meaningless if not compared to the spread of the ionian-attic koine. Civic communities might have been sociocentric, but it was the tension between their local agendas and their perception of the outside world that shaped their self-representations.

\section{Acknowledgments}

I am most grateful to Vincent Azoulay and Claudia Moatti for reading drafts of this chapter and suggesting improvements.

\section{References}

Azoulay, V. 2014. “Repenser le politique en Grèce ancienne.” Annales HSS 69, no. 3: 605626.

Beck, H. 2015. "The Parochial Polis: Localism and the Ancient Greek City-State, Projet 2015.”.

Bertrand, J.-M. 2005. “L'utopie magnète: réflexions sur les Lois de Platon.” In The Imaginary Polis, edited by M. H. Hansen, 152-163. Copenhagen: Det Kongelige Danske Videnskabernes Selskab.

Bresson, A. 2000. “Aristote et le commerce extérieur.” In La cité marchande, edited by A. Bresson, 109-130. Bordeaux: Ausonius.

Bresson, A. 2007. “L'entrée dans les ports en Grèce ancienne: le cadre juridique.” In Gens de passage en Méditerranée de l'Antiquité à l'époque moderne, edited by Cl. Moatti and W. Kaiser, 37-78. Paris: Maisonneuve \& Larose. 
Broodbank, C. 2013. The Making of the Middle Sea: A History of the Mediterranean from the Beginning to the Emergence of the Classical World. London: Thames \& Hudson.

Brunet, M. ed. 1999. Territoires des cités grecques. BCH suppl. 34. Paris and Athens: École française d'Athènes.

Buraselis, K. 2003. "Considerations on Symmachia and Sympoliteia in the Hellenistic Period." In Aspects of Connecting "Poleis" and "Ethnè" in Ancient Greece, edited by K. Buraselis et al., 39-50. The Idea of European Community in History II. Athens: National and Capodistrian University of Athens.

Cassayre, A. 2010. La justice dans les cités grecques, de la formation des royaumes hellénistiques au legs d'Attale. Rennes: Presses universitaires de Rennes.

Chambers, M. 1993. Hellenica Oxyrhynchia. Stuttgart: Teubner.

Chandezon, Chr. 2000. "Foires et panégyries dans le monde grec classique et hellénistique.” Revue des Études Grecques 113: 70-100.

Christesen, P., and D. G. Kyle, eds. 2013. A Companion to Sport and Spectacle in Greek and Roman Antiquity. Oxford: John Wiley \& Sons.

Cohen, E. E. 2000. The Athenian Nation. Princeton, NJ: Princeton University Press.

Cohen, G. M. 1995. The Hellenistic Settlements in Europe, the Islands and Asia Minor. Berkeley: University of California Press.

Dana, M. 2011. Culture et mobilité dans le Pont-Euxin. Bordeaux: Ausonius.

Dubois, L. 1996. Inscriptions grecques dialectales d'Olbia du Pont. Genève-Paris: Droz.

Eidinow, E. 2007. Oracles, Curses, and Risk among the Ancient Greeks. Oxford: Oxford University Press.

Gabrielsen, V. 2000. "The Synoikized 'Polis' of Rhodes." In Polis and Politics: Studies in ancient Greek history presented to M. H. Hansen, edited by P. Flensted-Jensen, Th. H. Nielsen, and L. Rubinstein, 177-205. Copenhagen: Museum Tusculanum Press.

Gagarin, M. 2005. "The Unity of Greek law." In The Cambridge Companion to Ancient Greek Law, edited by M. Gagarin and D. Cohen, 29-40. Cambridge, UK: Cambridge University Press. 
Gauthier, Ph. 2001. "Les Pidaséens entrent en sympolitie avec les Milésiens: la procédure et les modalités institutionnelles." In Les cités d'Asie Mineure occidentale au IIe s. av. J.C., edited by A. Bresson and R. Descat, 117-127. Bordeaux: Ausonius.

Gehrke H.-J. 2003. "Myth, History, and Collective Identity: Uses of the Past in Ancient Greece and Beyond." In The Historian's Craft in the Age of Herodotus, edited by N. Luraghi, 286-313. Oxford: Oxford University Press.

Hall, J. 1997. Ethnic Identity in Greek Antiquity. Cambridge, UK: Cambridge University Press.

Hall, J. 2002. Hellenicity. Between Ethnicity and Culture. Chicago: The University of Chicago Press.

Hansen, M. H. 1998. Polis and City-State. An Ancient Concept and Its Modern Equivalent. Copenhagen: The Royal Danish Academy of sciences and letters, Munksgaard.

Hansen, M. H., and Th. H. Nielsen, eds. 2004. An Inventory of Archaic and Classical Poleis. Oxford: Oxford University Press.

Harris, W. V. ed. 2005. Rethinking the Mediterranean. Oxford: Oxford University Press. Horden, P., and N. Purcell. 2000. The Corrupting Sea: A Study of Mediterranean History. Oxford: Blackwell.

Jeffery, L. H. 1982. “Greek Alphabetic Writting.” Cambridge Ancient History 3, no. 1: 819-33.

Jeffery, L. H. 1990. The Local Scripts of Archaic Greece. Revised edition with a supplement by A. W. Johnston. Oxford: Clarendon Press.

Kamen, D. 2013. Status in Classical Athens. Princeton, NJ: Princeton University Press.

Kearney, M. 1995. "The Local and the Global. The Anthropology of Globalization and Transnationalism." Annual Review of Anthropology 24: 547-565.

Kindt, J. 2012. Rethinking Greek Religion. Cambridge, UK: Cambridge University Press.

Konstan, D. 2009. "Cosmopolitan Traditions." In A Companion to Greek and Roman Political Thought, edited by R. K. Balot, 473-484. Oxford: Wiley-Blackwell.

Knoepfler, D. 2002. “Oropos et la Confédération béotienne à la lumière de quelques inscriptions 'revisitées'." Chiron 32: 119-155. 
Kyle, D. G. 2007. Sport and Spectacle in the Ancient World. Oxford: Blackwell.

Le Guen, Br. 2001. Les associations de technites dionysiaques à l'époque hellénistique. Nancy: Presses universitaires de Nancy.

Lefèvre, Fr. 1998. L'Amphictionie pyléo-delphique: Histoire et institutions. Paris-Athènes: École française d'Athènes.

López Eire, A. 1996. "L'influence de l'ionien-attique sur les autres dialectes épigraphiques et l'origine de la koinè." In La koinè grecque antique, Vol. II, La concurrence, edited by $\mathrm{Cl}$. Brixhe, 7-42. Nancy: Presses universitaires de Nancy.

Ma, J. 1999. Antiochos III and the Cities of Western Asia Minor. Oxford: Oxford University Press.

Ma, J. 2004. "You Can't Go Home Again: Displacement and Identity in Xenophon's Anabasis." In The Long March: Xenophon and the Ten Thousand, edited by R. Lane Fox, 330-345. Yale, CT: Yale University Press.

Mack, W. 2015. Proxeny and Polis: Institutional Networks in the Ancient Greek World. Oxford: Oxford University Press.

Mackil, E. 2013. "The Greek Koinon." In The Oxford Handbook of the State in the Ancient Near East and Mediterranean, edited by P. F. Bang and W. Scheidel, 304-323. Oxford: Oxford University Press.

Malkin, I., ed. 2001. Ancient Perceptions of Greek Ethnicity. Washington, DC: Centre for Hellenic studies, Trustees for Harvard University.

Malkin, I. 2005. "Networks and the Emergence of Greek Identity." In Mediterranean Paradigms and Classical Antiquity, edited by I. Malkin, 56-74. London and New York: Routledge.

Malkin, I. 2011. A Small Greek World: Networks in the Ancient Mediterranean. Oxford: Oxford University Press.

Malkin, I., Chr. Constantakopoulou, and K. Panagopoulou, eds. 2009. Greek and Roman Networks in the Mediterranean. London and New York: Routledge.

Mélèze-Modrzejewski, J. 2011. “Avant-propos.” In Droit grec d'Alexandre à Auguste, 323 av. J.-C.-14 ap. J.-C.: Personnes, biens, justice, edited by J. Vélissaropoulos-Karakostas, 15-20. Athènes: Centre de recherche de l'antiquité grecque et romaine Paris. 
Minon, S. 2014. "Introduction: Pour une géographie historique et sociale de la koinéisation du grec ancien." In Diffusion de l'attique et expansion des koinai dans le Péloponnèse et en Grèce centrale, edited by S. Minon, 1-18. Genève: Droz.

Morgan, C. 2003. Early Greek States beyond the Polis. London and New York: Routledge.

Müller, Chr. 2010. D'Olbia à Tanaïs: Territoires et réseaux d'échanges dans la mer Noire septentrionale aux époques classique et hellénistique. Bordeaux: Ausonius.

Müller, Chr. 2011. "Péri télôn: Quelques réflexions autour des districts de la Confédération béotienne à l'époque hellénistique." In Philologos Dionysios: Mélanges offerts au Professeur Denis Knoepfler, edited by N. Badoud, 261-282. Genève: Droz.

Müller, Chr. 2014a. "(De)constructing Politeia: Reflections on Citizenship and the Bestowal of Privileges Upon Foreigners in Hellenistic Democracies." Annales HSS 69, no. 3: 157-178.

Müller, Chr. 2014b. “A koinon after 146? Reflections about the Political and Institutional Situation of Boeotia in the Late Hellenistic Period." In The Epigraphy and History of Boeotia: New Finds, New Prospects, edited by N. Papazarkadas, 119-146.

Müller, Chr. 2015. “De l'époque classique à l'époque hellénistique: La citoyenneté des Grecs, une citoyenneté en mutation? Réflexions sur la question de l'appartenance multiple." Studi Ellenistici 29: 355-369.

Müller, Chr., and A.-E. Veïsse, eds. 2014. Culture matérielle et identité ethnique dans le monde grec, Dialogues d’histoire ancienne suppl. 10, Besançon.

Oliver, G. J. 2007. War, Food, and Politics in Early Hellenistic Athens. Oxford: Oxford University Press.

Pascual, J. 2007. “La sympoliteia greca en las épocas clasica y helenistica.” Gerion 25: 167-186.

Polignac, Fr. de. 1995. Cults, Territory, and the Origins of the Greek City-state. Chicago: University of Chicago Press.

Psoma, S. 2001. Olynthe et les Chalcidiens de Thrace: Études de numismatique et d'histoire. Stuttgart: F. Steiner.

Reger, G. 2004. "Sympoliteiai in Hellenistic Asia Minor." In The Graeco-Roman East: Politics, Culture, Society, edited by St. Colvin, 145-180. Cambridge, UK: Cambridge University Press. 
Rhodes, P. J., with D. M. Lewis. 1997. The Decrees of the Greek States. Oxford: Clarendon Press.

Rhodes, P. J., and R. Osborne. 2003. Greek Historical Inscriptions 404-323 BC. Oxford: Oxford University Press.

Rigsby K. J. 1996. Asylia: Territorial Inviolability in the Hellenistic World. Berkeley: University of California Press.

Rizakis, Ath. 2008. "L'expérience de l'organisation intercivique et supracivique dans la confédération achéenne." In Forme sovrapoleiche et interpoleiche di organizzazione nel mondo greco antico, edited by M. Lombardo and Fl. Frisone, 274-292. Galatina: Congedo.

Rizakis, Ath. 2012. "La double citoyenneté dans le cadre des koina grecs: L'exemple du koinon achéen." In Patrie d'origine et patries électives. Les citoyennetés multiples dans le monde grec d'époque romaine, edited by A. Heller and A.-V. Pont, 23-38. Bordeaux: Ausonius.

Robu, A. 2014. Mégare et les établissements mégariens de Sicile, de la Propontide et du Pont-Euxin: Histoire et institutions. Bern: P. Lang.

Roesch, P. 1989. “Décrets de proxénie d'Orchomène en Béotie.” In Architecture et poésie dans le monde grec: Hommages à Georges Roux, edited by R. Étienne, M.-Th. Le Dinahet, and M. Yon, 219-224. Lyon: Maison de l'Orient méditerranéen.

Savalli-Lestrade, I. 2012. "Collections de citoyenneté et internationalisation des élites civiques dans l'Asie mineure hellénistique." In Patrie d'origine et patries électives: Les citoyennetés multiples dans le monde grec d'époque romaine, edited by A. Heller and A.V. Pont, 39-59. Bordeaux: Ausonius.

Schmitt Pantel, P. $2011^{2}$. La cité au banquet: Histoire des repas publics dans les cités grecques. Paris: Publications de la Sorbonne.

Sourisseau, J.-Chr. 2012. “Documents archéologiques et réseaux d'échanges en Méditerranée centrale (VIIIe-VIIe s. a.C.)." In Mobilités grecques: Mouvements, réseaux, contacts en Méditerranée, de l'époque archaïque à l'époque hellénistique, edited by L. Capdetrey and J. Zurbach, 179-197. Bordeaux: Ausonius.

Van Bremen, R. 2003. "Family Structures." In A Companion to the Hellenistic World, edited by A. Erskine, 313-330. Oxford: Blackwell.

Vlassopoulos, K. 2013. Greeks and Barbarians. Cambridge, UK: Cambridge University Press. 
Whitmarsh, T. 2010. “Thinking Local." In Local Knowledge and Micro-Identities in the Imperial Greek World, edited by T. Whitmarsh, 1-16. Cambridge, UK: Cambridge University Press.

Will, Éd. $1979^{2}$. Histoire politique du monde hellénistique. Vol. I. Nancy: Presses universitaires de Nancy.

Woodard, R. D. 1997. “Greek Dialects." In The Cambridge Encyclopaedia of the World's Ancient Languages, edited by R. D. Woodard, 650-672. Cambridge, UK: Cambridge University Press. 